\title{
STUDY ON THE ABSENTEEISM OF NURSING PROFESSIONALS IN A PSYCHIATRIC CENTER IN MANAUS, BRAZIL
}

\author{
Sandra Greice Becker ${ }^{1}$ \\ Maria Luiza Carvalho de Oliveira ${ }^{2}$
}

Becker SG, Oliveira MLC. Study on the absenteeism of nursing professionals in a psychiatric center in Manaus, Brazil. Rev Latino-am Enfermagem 2008 janeiro-fevereiro; 16(1):109-14.

This quantitative study was performed to research the rate of absenteeism of nursing professionals in a psychiatric center in Manaus, from January/2004 to January/2005, in the Human Resources sector of the institution. In this period, the records of workers who were absent from their professional activities for at least one day were checked. Results showed that there were 415 absence reports in the nursing team during the studied period, by $74.29 \%$ of nursing professionals. The average rate of absenteeism is 2.79 . The main reason reported for absenteeism was illness. These data suggest further studies are needed in order to improve professionals' health, allowing for better quality of life, and, consequently, for providing better health care to Single Health System users.

DESCRIPTORS: absenteeism; nursing; occupational health

\section{ESTUDIO SOBRE AUSENTISMO EN PROFESIONALES DE ENFERMERÍA DEL CENTRO PSIQUIÁTRICO DE MANAUS, BRASIL}

Con el objetivo de investigar sobre el índice de ausentismo en trabajadores de enfermería del Centro Psiquiátrico de Manaus, se realizó una investigación cuantitativa durante el periodo de enero de 2004 a enero del 2005 en el sector de recursos humanos de la institución en mención. Durante este periodo se buscó a través de consulta documental, registros de los trabajadores que tuvieron faltas de por lo menos 1 día en sus actividades laborales. Los resultados mostraron que durante el periodo de la investigación, hubo 415 registros de faltas por parte del equipo de enfermería, totalizando $74,29 \%$. El índice del ausentismo profesional fue en promedio 2.79. Se observó que el principal motivo del ausentismo fue por enfermedad. Este hecho resalta la necesidad de mejorar la salud del trabajador, favoreciendo a una mejor calidad de vida en el trabajo y en consecuencia una mejor atención a la salud del usuario a través del SUS.

DESCRIPTORES: absentismo; enfermería; salud laboral

\section{ESTUDO DO ABSENTEÍSMO DOS PROFISSIONAIS DE ENFERMAGEM DE UM CENTRO PSIQUIÁTRICO EM MANAUS, BRASIL}

Com o objetivo de investigar o índice de absenteísmo dos trabalhadores de enfermagem de um Centro Psiquiátrico em Manaus, realizou-se esta pesquisa quantitativa, no período de janeiro de 2004 a janeiro de 2005, no setor de recursos humanos da instituição. Nesse período, buscou-se, por meio de consulta documental, registros dos trabalhadores ausentes das atividades laborais por, pelo menos, 1 dia. Os resultados indicaram que, no período pesquisado, houve 415 registros de ausência da equipe de enfermagem, tidas por $74,29 \%$ dos trabalhadores de enfermagem da instituição. A taxa de absenteísmo profissional é, em média, de 2,79. Verificouse ainda que o principal motivo do absenteísmo é por doença. Esse dado sugere estudos na busca da conquista de melhorar a saúde do trabalhador, possibilitar melhor qualidade de vida no trabalho e, conseqüentemente melhor assistência à saúde do usuário do SUS.

DESCRITORES: absenteísmo; enfermagem; saúde do trabalhador

${ }^{1}$ RN, Assistant Professor, e-mail: sgbecker@ufam.edu.br; ${ }^{2}$ Undergraduate Nursing Student. Federal University of Amazonas School of Nursing, Brasil. 


\section{INTRODUCTION}

$\boldsymbol{N}$ ursing professionals are frequently subjected to inappropriate working conditions, of physical or psychological origin, which harm their health and cause eating, sleeping, and evacuation disorders, as well as fatigue, aggravation to the body systems, decreased alertness, stress, family dysfunctions, and neurosis. These facts quite often cause occupational accidents and paid illness leaves for health treatments ${ }^{(1)}$. Work-related health risks depend on the type of professional activity and work conditions.

As a social variable, the work environment may be an important source of mental distress ${ }^{(2)}$. The factors of the work environment related to the healthdisease process include noise, poor lighting, extreme temperatures, vibrations, aesthetics, hygiene, and care. The factors related to work organization comprise task contents, working hours, excessive or insufficient physical and mental work, interpersonal relations at work, working pace and time pressure; impossibility of hierarchical ascension due to the nonimplementation of a career plan.

Absenteeism is an expression used to name the absence of an employee from work. It means the sum of the periods when the employees of a given organization are absent from work, as opposed to absence motivated by unemployment, prolonged disease or a legal leave from work ${ }^{(3)}$. Absenteeism in nursing is a concern because it disorganizes the work routine, causes dissatisfaction, and overburdens workers that are present, consequently lowering the quality of patient health care.

\section{ABSENTEEISM OF NURSING PROFESSIONALS}

Nursing is a human science, one that regards people and relationship experiences, with fields of knowledge, foundations, and praxis that comprehend states of health and disease. Therefore, it demands technical competence from the professionals, capacity of reflection, critical analysis, and constant improvement of his/her technical-scientific knowledge $^{(4)}$.

At hospitals, nursing is the largest workforce, with their activities recorded in task division. There is a clear hierarchical structure to accomplish routines, norms and regulations, and qualitative/quantitative dimensioning of insufficient personnel - a situation of professional activity reflected in high rates of absenteeism $^{(1)}$

Absenteeism may be directly related to the work conditions, reflecting on quality and productivity and on the personal life of the nursing professional. Hospitals provide their employees with work conditions that are notoriously worse than other health care services $^{(5)}$.

In the world of hospital work, nursing professionals are constantly exposed to occupational risks related to physical, chemical, and biological agents, and also to ergonomic and psychosocial factors. Work conditions in nursing imply long hours, working in wearying shifts (early and late night, Sundays and holidays), rounds, the multiplicity of functions, repetition and monotony, intensive and excessive working pace, anxiety, physical effort, awkward positions, separation of intellectual and manual work, control by the supervision, all of it capable of causing accidents and diseases. The occupational hazards range according to the activities performed and the environment. Risk overload may harm the worker's health, causing absenteeism ${ }^{(5)}$.

Dimensioning and qualitative/quantitative adequacy of the nursing workers are regulated by resolution \#293/2004 of the Federal Council of Nursing - COFEN, based on characteristics related to: the institution/company; the nursing services; the clientele; systems of classification of clients/patients (SCP), and the socio-cultural and economic reality. Considering this framework for the psychiatric ward, the client should be classified according to his/her service characteristics, adapting to the SCP in: minimum level of service or self-care, immediate service, semi-intensive service or intensive service. The special or psychiatric client with associated clinical or surgical issues must be classified as one level higher on the SCP, starting at the level of intermediary care ${ }^{(6)}$.

The overly high rate of absenteeism has become a problem for organizations and managers and worries nursing as a whole, since it reflects on care quality ${ }^{(7)}$. As such, the problematic of this study focuses on the question: What is the rate of absenteeism in the nursing team of a psychiatric center in Manaus?

The interest for studying the theme arose from practicing the discipline "Nursing in Mental and Psychiatric Health", where a deficiency in Human Resources was observed, due to the high demand by users. 
Such situation is presented as a challenge for the nursing managers to maintain service quality, added to the limitations in the performance of their functions due to work that require much physical effort. The absence of nursing employees disrupts teamwork and alters the quality and quantity of patient health care. Moreover, it causes problems with the nurses in management positions, because they are responsible for solving any administrative issues ${ }^{(5)}$.

On the other hand, with fewer workers, there is excessive workload. This unbalances the workers' health, which will often result in higher absenteeism in the health care institutions. This situation is a pathological cycle in the life of the institution ${ }^{(8)}$. Besides, when health care workers fall ill, especially those in the nursing careers, it results in direct consequences in the professional's quality of life and in service quality, patient welcoming, and the solution of health problems of SHS users.

This study assumes the definition of absenteeism as the designation of absence of employees at work, i.e., the sum of the periods when the workers of the organization are absent due to different causes, such as: absence, lateness, or some intervenient reason ${ }^{(3)}$.

\section{METHOD}

The method chosen was documental research, since this is a retrospective study in which the documented records of employee absence were analyzed in the Human Resources sector of the Psychiatric Center. The hospital is specialized in promoting mental health and is classified in the procedure: Treatment in a Psychiatric Hospital " $B$ " in the Group Hospitalization in Psychiatry IV [Tratamento em Hospital Psiquiátrico " $B$ " do Grupo de Internação em Psiquiatria IV] ${ }^{(9)}$.

The population of the study is composed by the nursing team, made up of the following professionals: 43 nursing auxiliaries, 16 health care assistants, 29 operational health care assistants, 6 nursing technicians, and 11 nurses, totaling 105 professionals in the nursing team.

The sample considered were the workers who are part of the nursing team and who had been absent from their professional activities for longer than one working day, from January/2004 to January/2005.
The inclusion criterion was that professionals were registered in the Human Resources sector, i.e., disregarding those who work as volunteers or interns in the institution. Of the total number of workers in the institution, with the exception of the administrative personnel, the nursing team represents $66 \%$ of the personnel in the Psychiatric Center, according to the data from September $15^{\text {th }}$, 2005.

The documents filed in the studied Human Resources sector were analyzed to collect the information, regarding the period from January/2004 to January/2005. The obtained results were examined by means of descriptive statistical analysis, using the EPI-INFO software, version 2003. These instruments allowed for the calculation of percentile absence rates by functional category.

Regarding ethical considerations, this research was primarily approved by the MedicalSurgical Nursing Department (DEMEC) of the Manaus College of Nursing (EEM) / Federal University of Amazonas (UFAM). It was then approved by the studied psychiatric center and by the UFAM Research Ethics Committee Involving Human Beings. Moreover, the confidentiality of the workers' identities was guaranteed, with the final results of the study being the only ones presented to the institution.

The study was developed within the program of Scientific Initiation of the Federal University of Amazonas - PIBIC/UFAM/2005-2006, with a scholarship by the Amazonas Research Foundation [Fundação de Amparo a Pesquisa do Amazonas] IC/FAPEAM.

\section{RESULTS}

Regarding the gender of the population, most of the 105 workers in the nursing team are women, as shown in Figure 1.

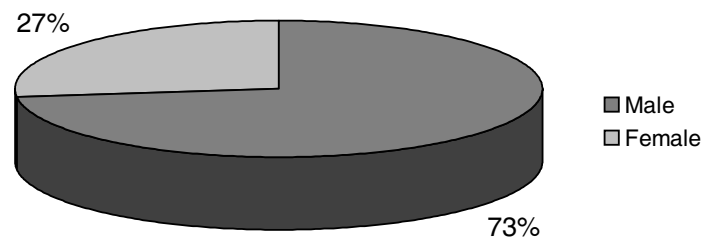

Figure 1 - Nursing Professionals according to gender, Manaus, AM, 2005 
The data show that $27 \%$ of the studied group are men while $73 \%$ of the workers are women, reaffirming the statistics that this predominance of females is a characteristics of the nursing profession. However, regarding workers' health, it is possible to associate it with the gender issue, since other studies report that women seek the Worker's Health care Service (SAST) more often than men do, and, also, the chance of a woman getting a paid leave is 1.59 times higher than a man's ${ }^{(10)}$. Such statistics should be taken into account for an adequate dimensioning of the nursing team.

Based on the COFEN resolution \#7498/86, the categories composing the nursing team are: nursing auxiliaries, nursing technicians, nurses, and midwives. In this sense, there is a particularity in the studied institution, where functional categories named Health Care Assistant and Operational Health Care Assistant were under the supervision of nursing. Such a fact might indicate the ineffectiveness or inexistence of a plan to promote the professional training of these workers in the institution, even with the efforts of the Federal Government in the institution of the PROFAE, which proposes professional training and qualification for these professionals.

Nursing is historically constituted as a profession strongly marked by vocation-based work, devotion, charity, abnegation, obedience, humility, and submission. For this reason, until today, there are relationships in nursing are where workers negate themselves, deny their condition as subjects, are obedient and acquiesce to what is imposed to them, regardless of distress ${ }^{(11)}$, and this may also limit the possibilities of effectively coping in the hospital environment.

Regarding age and time of service in the institution, most employees have been working for the studied institution for many years, which can be observed in relation to the average ages and times of service per professional category, according to Table 1.

Table 1 - Distribution of nursing workers per professional category and according to the average age of the studied population. Manaus, AM, 2005

\begin{tabular}{lcc}
\hline Professional Category & Average age Average time of service (years) \\
\hline Nursing technician & 56 & 19 \\
Health care assistant & 51 & 19 \\
Operational health care & 48 & 20 \\
assistant & 48 & 13 \\
Nurse & 33 & 6 \\
Nursing auxiliary &
\end{tabular}

Table 1 shows that workers are in a process of aging, since, with the exception of nursing auxiliaries, the average age of the other professionals is over 47 years, which suggests that they joined the institution a long time ago, without being repositioned after those categories had been extinct. This strengthens the inexistence of a career plan in the institution, which can be considered a negative variable in the rate of absenteeism.

As for the legal work regime, the institution follows the laws and statutes for state public servants. Therefore, according to institutional bonding, workers may be classified under temporary or statutory regime, and according to absences, as shown in Figure 2.

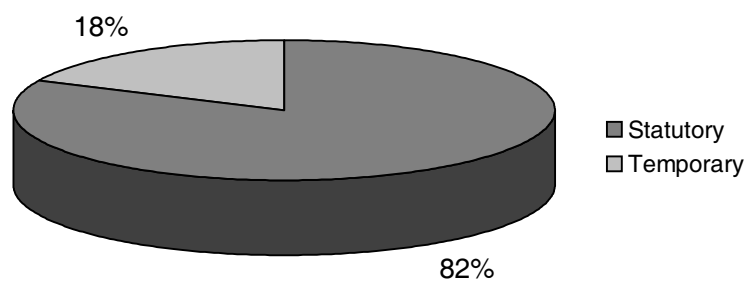

Figure 2 - Distribution of paid leaves according to the nursing workers' legal regime. Manaus, AM, 2005

Figure 2 shows that statutory workers are absent more often than those in a temporary working regime. Cross-referencing these data with the average age in Table 1, it can be observed that older workers are found in the statutory regime, considering both age and time of service. In addition, temporary workers also show the lowest average age and time of service, and the time of work in the institution is over 20 years for $48 \%$ of the nursing team. Such data suggests that time of service should be evaluated when analyzing absenteeism. Therefore, the workers who have been working in the institution the longest are not the ones who show a higher number of unplanned absence records. Nevertheless, those with a longer average time of service in the institution are those who are absent more days from their occupational activities (5 days, in average).

Considering the criteria established for recording nursing worker's absences in the studied institution, these were classified according to reason, shown in Figure 3.

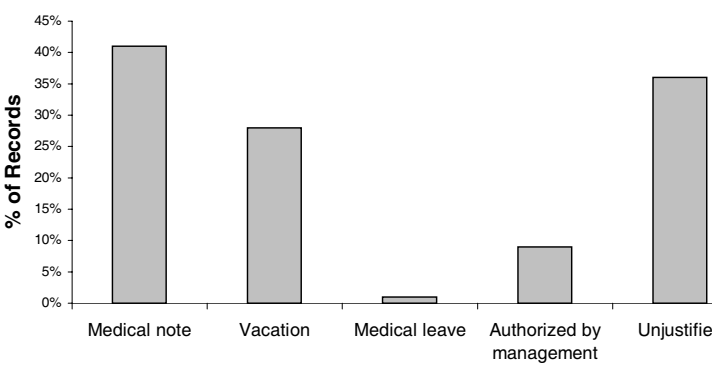

Figure 3 - distribution of absences according to reasons. Manaus, AM, 2005 
Considering only the unforeseen absences, 298 absences were recorded, with most of them $(57.05 \%)$ justified by medical notes, resulting in 464 days away from work in a one-year period.

There is also an alert for the possibility of unjustified absences (32.55\%) adding to absences due to disease, since brief health discomforts of the worker are self-medicated, not resulting in a visit to a physician's office with the consequent presentation of the medical note to the institution ${ }^{(8)}$.

Previous studies on absenteeism in hospitals have sought to research about the reasons that lead to illness leaves. Their results report the characteristics of the nursing activity and its consequent stress; lack of satisfaction at work; quality and quantity of human, physical and material resources; difficulties in the organization of care; disrespect to the Nursing professional legislation; individual factors ${ }^{(1,12)}$.

Researchers point out that the causes of absenteeism are not always found in the worker, but also in the company, which shows deficient organization and supervision, task repeatability, lack of motivation and stimuli, unfavorable environmental and working conditions, poor integration between the employees and the organization, and the psychological impacts of ineffective management, which does not aim towards humanistic and preventive policies.

However, while the day-to-day difficulties faced at work are understandable, it is seen that some nursing professionals submit to an excessive amount of activities and attributions that are not part of their competence, frequently submitting to those who attribute them activities that could be performed by others, possibly jeopardizing client health care. Apparently, they opt for omitting and denying themselves instead of saying yes to what they believe and know, argumentatively, confronting those who represent the power in their daily routine ${ }^{(11)}$. It is believed that these practices of challenging the power by nursing in hospital institutions may also be associated with an undesirable level of absenteeism.

To calculate the rate of absenteeism per functional category, the formula proposed by the COFEN resolution \#293/2004 was used, wherein vacation absences are not considered because they are classified as planned and scaled absences within a legal framework of working hours ${ }^{(1,6)}$, as seen in Table 2.
Table 2 - Rate of absenteeism calculated per functional category. Manaus, AM, 2005.

\begin{tabular}{lc}
\hline \multicolumn{1}{c}{ Functional Category } & Rate of Absenteeism \\
\hline Nursing auxiliary & 3.92 \\
Operational Health care Assistant & 3.27 \\
Nurse & 2.93 \\
Health care Assistant & 2.02 \\
Nursing Technician & 1.81 \\
\hline
\end{tabular}

Table 2 shows that, during the studied period, the Nursing auxiliaries was the category with the highest rate of absenteeism. These results are in harmony with other studies that also observed that, within the nursing team, the Nursing Auxiliary professional category was the one with the highest rate of absenteeism ${ }^{(1,12)}$.

\section{FINAL CONSIDERATIONS}

The findings show that nursing workers are mostly absent due to illness. The workers' quality of life, health conditions, and work satisfaction are essential for the quality of health care. In this sense, the data reinforce the need to develop health care strategies with the workers of the studied institution.

It is also verified that there are different behaviors between statutory and temporary regimes, with statutory workers being absent more frequently - maybe because temporaries, not being effectively hired, worry about the possibility of losing their jobs, which is not considered stable.

Out of the five professional categories that compose the nursing team, Nursing Auxiliaries and Operational Health Care Auxiliaries are those with the highest rate of absenteeism. This fact could be related to lower wages, lower technical-scientific instructional requirements, and higher physical demands to perform care, compared to the other categories.

Regarding the time of service in the institution, workers who have been working in the institution the longest also stay away the longest when falling ill. This suggests that the continuous exercise of nursing assistance, year after year, may cause physical and mental weariness in the caretaker, causing absences due to illness.

The study findings suggest the implementation of health care strategies with the nursing workers of the studied health care unit in order to reduce the number of absences in the work team due to disease and improve the quality of assistance and the level of satisfaction with work. Interventions on the promotion 
of workers' health and an adequate dimensioning of the nursing team would lower the economic and social costs of public health care. The authors also suggest that further qualitative studies should be developed, with the aim to add depth to the investigation about the nursing workers falling ill.

\section{REFERENCES}

1. Barboza DB, Soler ZA. Afastamentos do trabalho na enfermagem: ocorrências com trabalhadores de um hospital de ensino. Rev Latino-am Enfermqgem 2003 março-abril; 11(2):177-83

2. Rocha EL, Lima DMR. Distúrbios psíquicos relacionados ao trabalho. In: Ferreira M Jr, organizador. Saúde no Trabalho: temas básicos para o profissional que cuida da saúde dos trabalhadores. São Paulo (SP): Roca; 2000. p. 320-48.

3. Chiavenato I. Recursos Humanos: edição compacta. $6^{a}$ ed. São Paulo (SP): Atlas; 2000.

4. Escola de Enfermagem Anna Nery [Página na Internet]. Rio de Janeiro: Universidade Federal do Rio de Janeiro; c2003 [acesso em 2004 novembro 07]. Disponível em URL: http/ :www.eean.ufrj.br/

5. Silva DMP, Marziale MH. Absenteísmo de trabalhadores de enfermagem em um hospital universitário. Rev Latino-am Enfermagem 2000 setembro-outubro; 8(5):44-51

6. Ministério da Saúde (BR) [Página na Internet]. Conselho Nacional de Saúde. Resolução COFEN n 293/2004. Fixa e estabelece parâmetros para dimensionamento do quadro de profissionais de Enfermagem para as Unidades Assistenciais das Instituições de Saúde e Assemelhados. Brasília: Ministério da Saúde, 2004.[acesso em 2004 setembro 22]. Disponível em: http://www.bve.org.br/portal/ materias.asp?ArticleID $=1275 \&$ Section ID $=194 \&$ S ubSectionID = 194\&SectionParentID = 189

7. Nascimento GM. Estudo do absenteísmo dos trabalhadores de enfermagem em uma Unidade Básica e Distrital de Saúde do município de Ribeirão Preto- SP. [Dissertação on line] Ribeirão Preto (SP): Escola de Enfermagem/USP; 2003. [acesso em 2004 novembro 19]. Disponível em URL: http:// www.teses.usp.br/teses/disponiveis/22/22132/tde21052004-110529/

8. Becker SG. Cuidar de si, cuidando do outro, ampliando a consciência do eu. [dissertação] Porto Alegre (RS): Escola de Enfermagem/UFRGS; 2004.

9. Ministério da Saúde (BR). Conselho Nacional de Saúde. Doenças relacionadas ao trabalho: Manual de procedimentos para os serviços de saúde. Brasília (DF): Ministério da Saúde; 2001.

10. Reis RJ. Fatores relacionados ao absenteísmo por doença em profissionais de enfermagem. Rev Saúde Pública 2003 outubro; 37(5):616-23.

11 Beneri RL, Santos LR, Lunardi VL. O Trabalho da enfermagem hospitalar: o cuidado de si e o cuidado do outro. Rev Bras Enferm 2001 janeiro-março; 54(1):108-18.

12 Echer IC, Moura GM, Magalhães AM, Piovesan R. Estudo do absenteísmo como variável no planejamento de recursos humanos em enfermagem. Rev Gauch Enferm 1999 julho; 20(2):65-76. 